\title{
FREEZE-THAW PRETREATMENT OF POPLAR SAPWOOD DUST
}

\author{
Štefan Boháček, Andrej Pažitný, Michal Halaj, Jozef Balberčák, Vladimír Kuña \\ Pulp And Paper Research Institute \\ SLOVAKIA
}

(Received April 2020)

\begin{abstract}
The paper is focused on the effect of freezing and cyclic freezing-thawing pretreatment of poplar sapwood (Populus alba L.). The experimental comparison was carried out by the sawdust fraction $0.7 \mathrm{~mm}$ as $(a)$ water-saturated and $(b)$ dry. Monosaccharide yields, as well as an amount of acetic acid, were measured after 6, 24, 48, 72, and 96 hours of enzymatic hydrolysis with $15 \%$ load of the enzyme measured to total cellulose content. The influence of freezing rate on total yields was observed on equally prepared samples with different weights $(31 \mathrm{~g}, 25 \mathrm{~g}, 62.5 \mathrm{~g}$, $125 \mathrm{~g}, 250 \mathrm{~g}, 500 \mathrm{~g}$, and $1000 \mathrm{~g}$ ) by "cubic" tests. To increase the efficiency of pretreatment, a cyclic freezing-thawing experiment at temperatures $-20^{\circ} \mathrm{C}$ and $+25^{\circ} \mathrm{C}$ was performed. The results show that single freezing of grounded poplar sapwood impregnated by water or dry in its matter is not a sufficient pretreatment method, so cyclic freeze-thaw is needed to enhance the yield of monosaccharides. Analysis of cubic test showed that slower freezing process has a positive effect on enzyme accessibility.
\end{abstract}

KEYWORDS: Pretreatment, freezing-thawing, poplar, Populus alba L., monosaccharides, sapwood, wood fractions.

\section{INTRODUCTION}

The pretreatment is required to increase the accessibility of enzymes in lignocellulosic materials (LCM). The pretreatment methods are divided into: physical (milling, extrusion, microwave, cryolysis), chemical (acid pretreatment, alkaline pretreatment, ionic liquid pretreatment, organosolv pretreatment, ozonolysis), physicochemical (steam explosion pretreatment, ammonia fiber explosion pretreatment, $\mathrm{CO}_{2}$ explosion pretreatment, liquid hot water, wet oxidation) and biological (fungi), and combination of these methods (Mood et al. 2013, Gigac et al. 2017, Stankovská et al. 2018).

This paper focuses on a lighter form of cryolysis at lower freeze temperatures, i.e., physical pretreatment. The principle of this method is to change the volume of water during freezing. The 
biomass mixed with water is put into a freezer until the whole material is frozen. Water diffused into the biomass during impregnation process increases the volume during freezing, thereby disrupting the cell walls' structure. Results in the opening and rising of the biomass surface for enzymatic hydrolysis (Rooni et al. 2017). The crystallization rate is an essential parameter for cryolysis because of a longer time for crystals to grow results in a larger size (Moore and Molinero 2011). In most publications, agricultural waste is used as a substrate, such as rice straw (Chang et al. 2011, Deng et al. 2018), wheat straw (Wang et al. 2013, Ihnát et al. 2015, Pažitný et al. 2019a, Sasaki et al. 2020), barley straw (Rooni et al. 2017), corncobs and corn stalks (Echeverria et al. 2018, Yuan et al. 2019, Li et al. 2019a). Other types of cryolysis substrate were: grasses, such as switchgrass (Panicum virgatum) (Yang et al. 2009), rush (Juncus maritimus) (Smichi et al. 2016), waste cotton towels (Sasaki et al. 2020), and poplar wood (Zhu et al. 2020). The cellulose content of all these materials is comparable, including grasses such as switchgrass (Pažitný et al. 2013). However, it can be mildly higher in wood materials. In addition, these materials reach relatively low basic density compared to hardwood deciduous species (Petráš et al. 2019) which is suitable in pretreatment processes. Waste grade paper (Russ et al. 2013) may be an efficiently processing substrate due to its advanced microstructure opening stage. and also algal biomass, because the cell walls of algae (including microalgae) do not contain lignin, thus, they are less recalcitrant to degradation, than lignocellulose materials (Yazdani et al. 2015, Halaj et al. 2018).

For more compact wood material, freezing is combined with inorganic solvents in more publications. Jeong et al. (2016) observed the effect of freezing on Mongolian oak (Quercus mongolica) impregnated by $1 \% \mathrm{H}_{2} \mathrm{SO}_{4}$, also was studied a combination of freezing-thawing (from -20 up to $20^{\circ} \mathrm{C}$ ) with added ammonia ( $\mathrm{Li}$ et al. 2019b) or added $\mathrm{NaOH}$ (Su and Fang 2017, Sasaki et al. 2020). Finer chemical processes that are more gentle on the wood substrate can be used (Balberčák et al. 2017, 2018).

With growing government, academic, and commercial research on the production of biofuels from lignocellulosic biomass, several species have appeared as front-runners in this field. This paper focuses on white poplar (Populus alba L.), also known as Silver poplar or Silver leaf poplar. Poplars are fast-growing trees, with various utilizations, like biofuels, pulp, paper production, and other biobased chemicals (Tuskan 2006).

Generally, LCM are composed of cellulose (35-50\%), hemicelluloses (20-35\%), lignin (15-20\%), ash, and other components (15-20\%) (Mood et al. 2013). Cellulose and hemicelluloses in the LCM create a complex that is an obstacle to enzyme access under natural conditions. Moreover, the cellulose-hemicellulose complex is encapsulated by lignin, which increases the biomass hydrolysis barrier (Taha et al. 2016). In order to obtain fermentable sugars, pretreatment of LCM before enzymatic hydrolysis is needed to decompose the lignin-cellulose-hemicellulose complex in macroscopic, submicroscopic, and microscopic structure (Fu and Mazza 2011). Another hurdle to enzymatic hydrolysis and subsequent fermentation of LCMs is the generation of lignocellulose-derived by-products that inhibit these reactions. These by-products are formed by the decomposition of hemicelluloses and lignin, which include aliphatic acids (e.g., sugar acids, formic acid, acetic acid, levulinic acid), furan derivatives (e.g., hydroxymethylfurfural, furfural), and phenolic compounds (Jönsson et al. 2013, Palmqvist and Hahn-Hägerdal 2000). The content of cellulose and lignin in wood gradually increases with age, while the content of hemicellulose composed of pentosans decreases (Pazitny et al. 2020). 


\section{MATERIAL AND METHODS}

\section{Material}

The White poplar (Populus alba L.) wood was obtained from the Bratislava area (SK). The 12-year-old wood cut-out had a significantly different core and outer part. The harvesting of the material was performed in November. The enzyme complex Cellic ${ }^{\circledR} \mathrm{CTec} 3$ was supplied by Novozymes A/S (Bagsværd, Denmark). The enzyme activity was measured to be $1700 \mathrm{BHU}$ (Biomass Hydrolysis Units)/g product in the laboratory.

\section{Methods}

Sample preparation

The timber of white poplar was stripped of leaves, debarked, separated to heartwood and sapwood. Only sapwood was used for the experiment. The wood's separated parts were crushed for chips with a thickness below $0.3 \mathrm{~mm}$ and dried under laboratory temperature for more than two months. The chips were then dry milled in a Brabender mill (Brabender ${ }^{\circledR}, \mathrm{GmbH} \&$ Co. KG, Germany) with a bottom sieve $0.7 \mathrm{~mm}$ mesh. The fraction composition of wooden dust $0.7 \mathrm{~mm}$ was determined by sieve tester after $5 \mathrm{~min}$ of sieving.

\section{Determination of chemical composition}

The content of ash was determined according to ISO 1762, the content of extractives in dichloromethane and hot water according to Tappi T $204 \mathrm{~cm}-94$, and Tappi T $207 \mathrm{~cm}-08$. The Tappi T 222 om-98 was used for the determination of Klason lignin, and Tappi UM 250 for the determination of acid-soluble lignin. The holocellulose content in the analyzed samples was determined according to Wise's method, and cellulose content according to ISO 692.

\section{Determination of content of elements}

The content of elements $\mathrm{K}, \mathrm{Ca}, \mathrm{Mg}, \mathrm{Na}, \mathrm{Fe}, \mathrm{Mn}, \mathrm{Zn}, \mathrm{Cu}$ in-branch timber was determined by atomic absorption spectroscopy (AAS) with flame atomization according to Tappi T 266. To determine the content of the elements, a part of the obtained ash was dissolved in hydrochloric acid. The phosphorus content was determined by spectrometry with ammonium molybdate, according to STN EN ISO 6878. The content of Si in the wood was determined from the insoluble part by gravimetric determination of $\mathrm{SiO}_{2}$ after dissolving in hydrofluoric acid.

\section{Freezing pretreatment}

A quick determination of the dry matter $94.2 \%$ in samples was performed on moisture analyzer Denver IR35 that uses infrared heating. For the comparison of experimental results, samples for freezing were prepared as sawdust saturated by water, and dry (unsaturated) sample as a blank: (a) $12.5 \mathrm{~g}$ of sawdust of absolute dry weight $+86.7 \mathrm{ml}$ of distilled water (full saturated cells), (b) $12.5 \mathrm{~g}$ of sawdust of absolute dry weight (moisture content of 5.8\%). The samples were prepared in closed PET bags and placed for impregnation into the orbital shaker-incubator 24 hours at $60^{\circ} \mathrm{C}$. Freezing of sealed PET bags was performed at $-20^{\circ} \mathrm{C}$ for 24 hours. After freezing, the samples were thawed for 24 hours as well.

Enzymatic hydrolysis

Enzymatic hydrolysis was performed using Cellic Ctec 3 at 15\% w/w (g Cellic Ctec 3/100 g suspension) in orbital shaker-incubator ES-20/60 (BioSan Ltd., Republic of Latvia) at $50^{\circ} \mathrm{C}$, $\mathrm{pH}=5.0$ for 48 hours. The $\mathrm{pH}$ value was regulated during the hydrolysis process using $0.1 \mathrm{~N}$ 
sulphuric acid or $0.1 \mathrm{~N}$ sodium hydroxide. Sampling from hydrolysates for the determination of monosaccharides was performed after 6, 24, 48, 72, and 96 hours.

\section{Determination of monosaccharides concentration}

The determination was carried out according to the procedure of the National Renewable Energy Laboratory (Sluiter et al. 2008). Monosaccharides (glucose, xylose, and arabinose) in hydrolysates were determined by HPLC with Rezex ROA (organic acid) $\mathrm{H}+$ column, with $0.005 \mathrm{~N}$ sulphuric acid as the mobile phase during flow rate of $0.5 \mathrm{~mL} \cdot \mathrm{min}^{-1}$ and temperature $30^{\circ} \mathrm{C}$. Chromatography data were collected and analyzed by the software Clarity version 5.3.0.180 (DataApex Ltd., Czech Republic).

\section{Freezing kinetics}

The experimental analysis of freezing rate was carried out on samples of (Populus alba L.) wood dust of $0.7 \mathrm{~mm}$ fraction, prepared according to the upper described procedure. The experiments were carried out with samples of weight $31 \mathrm{~g}, 25 \mathrm{~g}, 62.5 \mathrm{~g}, 125 \mathrm{~g}, 250 \mathrm{~g}, 500 \mathrm{~g}$, and $1000 \mathrm{~g}$. The samples were wholly impregnated by distilled water and pretreated by cryolysis at various freezing rates in prepared laboratory cubes (Fig. 1). The laboratory cubes were put into a laboratory freezer with a constant temperature of $-20^{\circ} \mathrm{C}$. After cryolysis, the samples were subjected to enzymatic hydrolysis at temperature $50^{\circ} \mathrm{C}$, the concentration of $12.5 \%$ of absolute dry weight /100 $\mathrm{g}$ of heterogeneous mixture water-biomass) with added $15 \mathrm{~g}$ of enzyme CELLIC ${ }^{\circledR}$ CTec 3 for $100 \mathrm{~g}$ of the sample's absolute dry weight. After 48 hours of hydrolysis, the contents of monosaccharides (glucose, xylose, and arabinose) as products were analyzed.

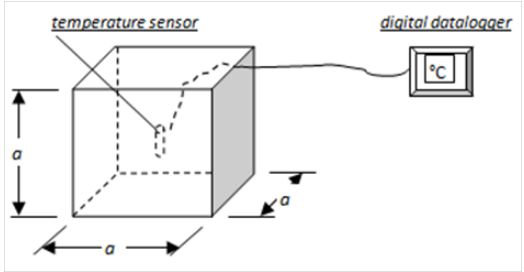

Fig. 1: Assessment of the laboratory analysis of freezing rate ("cubic test"). Cubes made of polycarbonate boards $5 \mathrm{~mm}$ were dimensioned (the measure " $a$ ") so that their volume corresponds to the weights of the samples $(31 \mathrm{~g}, 25 \mathrm{~g}, 62.5 \mathrm{~g}, 125 \mathrm{~g}, 250 \mathrm{~g}, 500 \mathrm{~g}$, and $1000 \mathrm{~g})$.

\section{Cyclic freezing and thawing}

The effect of cyclic freezing and thawing was performed under conditions defined in Tab. 1 on samples of (Populus alba L.) wood sawdust of $0.7 \mathrm{~mm}$ fraction, prepared according to the procedure upper described.

Tab. 1: Conditions for the cyclic freezing and thawing pretreatment of wood sawdust $0.7 \mathrm{~mm}$ of Populus alba L. (sapwood).

\begin{tabular}{|c|c|}
\hline Freezing $-\mathbf{2 0}^{\circ} \mathbf{C}$ & Thawing $+25^{\circ} \mathbf{C}$ \\
\hline $1^{30}$ hour & $1^{30}$ hour \\
\hline
\end{tabular}

Samples were prepared as $12.5 \mathrm{~g}$ absolutely dried wood sawdust $0.7 \mathrm{~mm}$ in PET bags impregnated by $86.7 \mathrm{ml}$ distilled $\mathrm{H}_{2} \mathrm{O}$. The same procedure, as previously mentioned, was used. 


\section{RESULTS AND DISCUSSION}

Poplar is one of the trees with the highest growth rate and the highest heating values; its hardwoods are also one of the most utilized in several countries. The poplar timber is used in the furniture and paper industries and for pallets and plywood production. For the accessibility of the enzyme, the fraction with the smallest particles was used to attain a highly reactive surface (Pazitny et al. 2019b). Authors focused on pretreatment of lignocellulosic materials used fine straw fractions mesh $0.25 \mathrm{~mm}$ (Wang et al. 2013), but whole stems and leaves of switchgrass were placed for long-term freezing subsequently reduced in size on a $2 \mathrm{~mm}$ screen (Yang et al. 2009). The sieve tests determined four fractions of the fractional composition. (Tab. 2).

Tab. 2: Sieve tests of poplar wood (sapwood) milled on knife mill with a bottom sieve of $0.7 \mathrm{~mm}$ mesh.

\begin{tabular}{|l|c|c|c|c|c|}
\hline Sieve mesh $(\mathrm{mm})$ & $0.7-0.4$ & $0.4-0.25$ & $0.25-0.18$ & $0.18-0$ & Total \\
\hline Poplar - sapwood & $9.7 \mathrm{~g}$ & $15.7 \mathrm{~g}$ & $13.4 \mathrm{~g}$ & $11.2 \mathrm{~g}$ & $50.0 \mathrm{~g}$ \\
\hline
\end{tabular}

The fraction of mesh $0.4-0.25 \mathrm{~mm}$ was representative (30\%). The sufficient fraction that should be the most available for the enzymes occupies below 20\% (Fig. 2). Content of fine fractions after dry milling, obtained using knife mills as Brabender, is higher if the wood mass is dried before the process used in this case (dry matter 94.2\%). Another possibility to disrupt the wood mass is wet milling (Ihnát et al. 2018), however, this method usually requires to increase temperature (Pažitný et al. 2019). On the other hand, the total impregnation of very dried wood material is difficult, causing complications during the enzymatic hydrolysis.

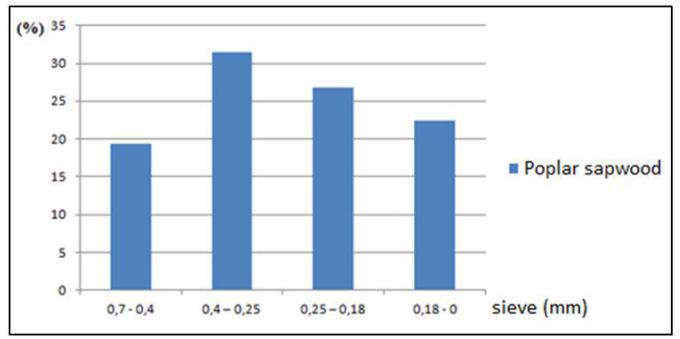

Fig. 2: Fractional composition of poplar sawdust $0.7 \mathrm{~mm}$ (\%).

Tab. 3 shows the chemical composition of poplar sapwood determined by chemical analyses according to appreciated methods. The content of cellulose in the poplar sapwood is $49.9 \% \mathrm{w} / \mathrm{w}$ o.d., the content of hemicellulose is $25.4 \%$, the total content of lignin and extractives were $21.6 \%$ and $2.3 \%$, resp. The cellulose content in Populus alba in the literature ranges between 52\% - 56\% and hemicellulose $15 \%-23 \%$, the content of lignin $16 \%-20 \%$. The range of extractives in Populus alba in literature was found as $7 \%-10 \%$. Content of ash was determined by Gökkaya et al. (2020) as $2.6 \%$. The results reveal that the contents of principal components (cellulose, hemicellulose, and lignin) correspond to results already published, but the contents of extractives and ash were different. However, it must be mentioned that various combinations of solvents for extraction were used for their determination. The contents of cellulose, hemicellulose, and lignin in various species of poplars range from $42 \%$ to $56 \%, 15 \%$ to $26 \%$; and $16 \%$ to $27 \%$, respectively (Rowell et al. 2005, Gökkaya et al. 2020, Rego et al. 2019). The content of chemical elements in poplar sapwood ash (Populus alba L.) is shown in Tab. 4. 
Tab. 3: Chemical composition of poplar saprwood (Populus alba L.).

\begin{tabular}{|l|c|c|}
\hline & White poplar sapwood & Methods \\
\hline Ash (\%) & $\mathbf{0 . 8 7}$ & ISO 1762 \\
\hline Extractives & 0.64 & Tappi T 204 cm-94 \\
\hline Dichloromethane (\%) & 1.63 & Tappi T 207 cm-08 \\
\hline Hot water (\%) & $\mathbf{2 . 2 7}$ & \\
\hline Total (\%) & 19.31 & Tappi UM 250 \\
\hline Lignin & 2.24 & Wise method \\
\hline *Klason (\%) & $\mathbf{2 1 . 5 5}$ & ISO 692 \\
\hline Acid-soluble (\%) & $\mathbf{7 5 . 3 0}$ & 49.90 \\
\hline Total (\%) & Holocellulose (\%) &
\end{tabular}

*Klason lignin is corrected to the ash content of Klason lignin.

Tab. 4: The content of chemical elements in poplar sapwood ash (Populus alba L.).

\begin{tabular}{|c|c|c|c|}
\hline \multicolumn{4}{|c|}{ Populus alba (sapwood) } \\
\hline Chemical element & Content $\left(\mathrm{mg}^{\mathrm{k}} \mathrm{kg}^{-1}\right)$ a.d. & Chemical element & Content $\left(\mathrm{mg}^{\mathrm{kg}}{ }^{-1}\right)$ a.d. \\
\hline $\mathrm{K}$ & 1289.6 & $\mathrm{Fe}$ & 8.3 \\
\hline $\mathrm{Ca}$ & 792.2 & $\mathrm{Mn}$ & 1.1 \\
\hline $\mathrm{Mg}$ & 230.8 & $\mathrm{Si}$ & 43.6 \\
\hline $\mathrm{Na}$ & 83.4 & $\mathrm{Zn}$ & 20.6 \\
\hline $\mathrm{P}$ & 55.1 & $\mathrm{Cu}$ & 3.5 \\
\hline
\end{tabular}

*a.d. - absolutely dry.

\section{The dependence of monosaccharide yields on the duration of enzymatic hydrolysis}

The dependence of the yields of monosaccharides as well as the production of acetic acid on the duration of enzymatic hydrolysis is reported in Tab. 5. The results show that single freezing is without the desired effect. In this case, it is not related to the sample's impregnation, thus whether the sample is entirely impregnated or relatively dry. The yields of monosaccharides depend only on the duration of enzymatic hydrolysis. The yields of glucose $19.5 \mathrm{~g} \cdot \mathrm{1}^{-1}$ are significantly lower than after other pretreatment types, e.g., the steam explosion of the same sample at temperature $200^{\circ} \mathrm{C}\left(70.4 \mathrm{~g} \cdot \mathrm{1}^{-1}\right)$ (Pažitný et al. 2020).

Tab. 5: Enzymatic hydrolysis of poplar wood after freezing pretreatment.

\begin{tabular}{|c|c|c|c|c|c|c|}
\hline Sample & $\begin{array}{c}\text { Duration } \\
\text { (yield) }\end{array}$ & $\begin{array}{c}6 \mathrm{~h} \\
\left(\mathrm{~g} \cdot \mathrm{l}^{-1}\right) \\
\end{array}$ & $\begin{array}{l}24 \mathrm{~h} \\
\left(\mathrm{~g} \cdot \mathrm{l}^{-1}\right)\end{array}$ & $\begin{array}{l}48 \mathrm{~h} \\
\left(\mathrm{~g} \cdot \mathrm{l}^{-1}\right)\end{array}$ & $\begin{array}{l}72 \mathrm{~h} \\
\left(\mathrm{~g} \cdot \mathrm{l}^{-1}\right)\end{array}$ & $\begin{array}{r}96 \mathrm{~h} \\
\left(\mathrm{~g} \cdot \mathrm{l}^{-1}\right) \\
\end{array}$ \\
\hline \multirow{3}{*}{$\begin{array}{l}\text { Freezing of water- } \\
\text { saturated samples } \\
-20^{\circ} \mathrm{C} \text { for } 24 \text { hour }\end{array}$} & Glucose & 13.7 & 19.5 & 23.4 & 24.8 & 29.2 \\
\hline & Xylose & 3.84 & 5.8 & 6.73 & 6.9 & 8.0 \\
\hline & Acetic acid & 0.4 & 0.65 & 0.75 & 0.8 & 0.88 \\
\hline \multirow{3}{*}{$\begin{array}{l}\text { Freezing of dry } \\
\text { fraction (*MC } 5.8 \%)\end{array}$} & Glucose & 14.2 & 19.5 & 23.2 & 24.7 & 27.9 \\
\hline & Xylose & 4.2 & 5.6 & 6.4 & 6.6 & 7.6 \\
\hline & Acetic acid & 0.37 & 0.6 & 0,73 & 0.76 & 0.89 \\
\hline
\end{tabular}

${ }^{*} \mathrm{MC}$ - moisture content. 


\section{Kinetics of freezing}

Due to the low yields, further we focused on the kinetics of the destructive effect. The destructive effect for biomass is possible to assume only if ice crystals' formation begins, i.e., temperature from $0^{\circ} \mathrm{C}$ to $-5^{\circ} \mathrm{C}$. The following decrease of temperature should result in the formation of crystals in lumens of biomass cells much deeper, together with raising volume during the phase transition of water into ice in the lumens, which causes disruption of the crystalline structure of cellulose and increases its accessibility in following hydrolysis processing. The rate of freezing was tested on "cubic tests". The samples were placed into cubes at the same ambient conditions with constant temperature $-20^{\circ} \mathrm{C}$, so the freezing in the core of the cube started in various times, i.e., forming of crystals was slower at a higher volume. The temperature in the cube core was measured by using a temperature sensor.

\section{Cubic tests results}

Monosaccharide concentrations after the 48-hour enzymatic hydrolysis of the 0.7 sawdust poplar pretreated by single freezing using the cubic test method are shown in Tab. 6. Glucose yields have been obtained in range $19.9 \mathrm{~g} \cdot \mathrm{l}^{-1}$ to $24.3 \mathrm{~g} \cdot \mathrm{l}^{-1}$, xylose $4.0 \mathrm{~g} \cdot \mathrm{l}^{-1}$ to $5.24 \mathrm{~g} \cdot \mathrm{l}^{-1}$ and arabinose $0.3 \mathrm{~g} \cdot \mathrm{l}^{-1}$ to $3.13 \mathrm{~g} \cdot \mathrm{l}^{-1}$. Total monosaccharide yields after a single freeze pretreatment such range from 24.2 to $31.87 \mathrm{~g} \cdot \mathrm{1}^{-1}$.

Tab. 6: Dependence of monosaccharide concentrations after 48 b enzymatic hydrolysis on the kinetics of freezing.

\begin{tabular}{|c|c|c|c|c|}
\hline \multicolumn{5}{|c|}{ Monosaccharide content $\left.\mathbf{~ ( g . ~}^{\mathbf{1}} \mathbf{~}\right)$} \\
\hline Freezing time (h) & Glucose & Xylose & Arabinose & Total \\
\hline 0 & 19,90 & 4.00 & 0,30 & 24,20 \\
\hline 0.5 & 21.10 & 4.20 & 0.75 & 26.05 \\
\hline 1 & 21.90 & 4.40 & 1.21 & 27.55 \\
\hline 2 & 22.80 & 4.71 & 1.76 & 29.27 \\
\hline 4 & 23.10 & 5.10 & 2.30 & 30.33 \\
\hline 8 & 23.60 & 5.17 & 2.24 & 31.01 \\
\hline 12 & 24.30 & 5.24 & 3.13 & 31.87 \\
\hline
\end{tabular}

The cubic test analysis shows (Fig. 3) that a slower freezing process positively affects the degradation of the crystalline structure of cellulose in the samples, thus on enzyme accessibility. Hence, the longer the freezing time, the higher the effect.

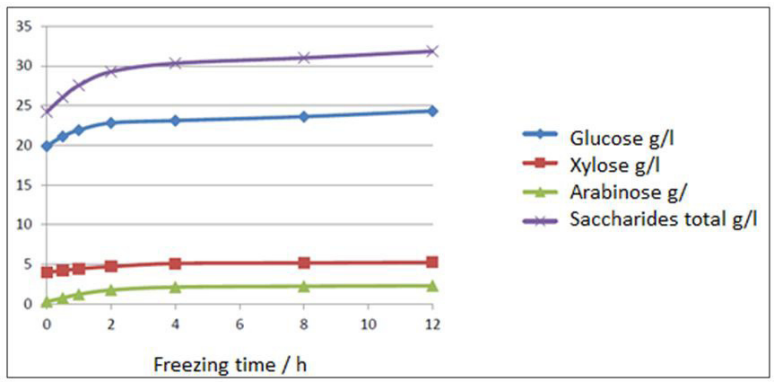

Fig. 3: Dependence of monosaccharide concentration after 48 hours enzymatic hydrolysis on the kinetics of freezing the biomass pretreated by cryolysis. 
The slow freezing process causes first changes on the impregnated biomass particles; the surface is trapped, becomes hard and brittle. In the following slower process of crystal formation and changing of water volume during the transition from liquid to solid state, results to use maximal destruction effect of the crystal growth and volume change.

During the freezing process, the surface temperature is lower than in the lignocelluloses' core (Chang et al. 2011). When the temperature decreases during the freezing, the volume of free water grows in the pores, and molecules of water have to surpass the viscous resistance, resulting in pressure gradients of the water that should significantly damage the lignocellulose structure (Chang et al. 2011). The adsorption of water molecules occurs only in the amorphous part of cellulose, where the bounded water forms hydrogen bonds with hydroxyl groups. The inner volume of the lignocellulose structure increases due to decreased cohesion; the solids get softer and occurs swelling. The destruction of the lignocellulose structure is a result of the expansion of water volume during the freezing.

\section{Effects of cyclic freezing and thawing on monosaccharide yields}

The best results were obtained by cyclic freezing-thawing. Tab. 7 contains monosaccharide concentrations of $0.7 \mathrm{~mm}$ sawdust of Populus alba (sapwood) after 48 hours of enzymatic hydrolysis depended on the number of cycles freeze-thaw pretreatment. In total, 20 cycles of freezing-thawing were performed.

Tab. 7: Dependence of monosaccharide concentrations of Populus alba (sapwood) after 48 hours enzymatic bydrolysis on number of cycles freeze-thaw pretreatment.

\begin{tabular}{|c|c|c|c|c|c|}
\hline \multicolumn{6}{|c|}{ Cyclic freezing-thawing of poplar (sapwood) sawdust $0.7 \mathrm{~mm}$} \\
\hline \multicolumn{6}{|c|}{ Monosaccharide content $\left(\mathrm{g} \cdot \mathrm{l}^{-1}\right)$} \\
\hline Cycles & Glucose & Xylose & Arabinose & Acetic acid & \multirow{10}{*}{$\begin{array}{c}\text { Enzymatic } \\
\text { hydrolysis } \\
48 \text { hour }\end{array}$} \\
\hline Without freezing & 20.6 & 4.4 & 0.16 & 0.59 & \\
\hline Freeze- thaw $1 \mathrm{x}$ & 20.7 & 4.6 & 0.16 & 0.60 & \\
\hline Freeze- thaw $2 \mathrm{x}$ & 20.5 & 4.8 & 0.17 & 0.63 & \\
\hline Freeze- thaw $5 \mathrm{x}$ & 21.4 & 4.9 & 0.18 & 0.64 & \\
\hline Freeze- thaw $7 \mathrm{x}$ & 21.6 & 5.1 & 0.18 & 0.67 & \\
\hline Freeze- thaw $10 \mathrm{x}$ & 24.4 & 5.8 & 0.20 & 0.69 & \\
\hline Freeze- thaw $12 \mathrm{x}$ & 27.4 & 6.7 & 0.21 & 0.72 & \\
\hline Freeze- thaw $17 \mathrm{x}$ & 31.2 & 7.9 & 0.25 & 0.81 & \\
\hline Freeze- thaw $20 \mathrm{x}$ & 35.6 & 8.6 & 0.29 & 0.99 & \\
\hline
\end{tabular}

The yield of glucose was increased from $20.6 \mathrm{~g} \cdot \mathrm{l}^{-1}$ to $35.6 \mathrm{~g} \cdot \mathrm{l}^{-1}$. Also, the yield of xylose was increased, from $4.4 \mathrm{~g} \cdot \mathrm{l}^{-1}$ to $8.6 \mathrm{~g} \cdot \mathrm{l}^{-1}$. The total yield of arabinose was negligible (from $0.16 \mathrm{~g} \cdot \mathrm{l}^{-1}$ up to $0.29 \mathrm{~g} \cdot 1^{-1}$ ). The dependence of monosaccharide yields on the number of cycles is shown in Fig. 4.

The effect of cyclic freezing-thawing was also validated by Zhu et al. (2020). They carried out freeze-thaw repetition (1-6 times) of poplar chips. A hemicellulose yield of $85.87 \mathrm{mg} \cdot \mathrm{g}^{-1}$ (showing an increase of $32.25 \%$ over that of untreated poplar chips) was obtained after freeze-thawed four times at $-20{ }^{\circ} \mathrm{C}$ and then hydrolyzed by hot water for one hour at $170^{\circ} \mathrm{C}$, consequently.

Freeze-thaw repetition pretreatment results in lowered molecular weight and enhanced concentration of monosaccharides. This process indicates the creation of irregular micro slits and pores, thus increasing fibrous cell wall debris, which significantly contributed to hemicelluloses' dissolution rate (Zhu et al. 2020). 


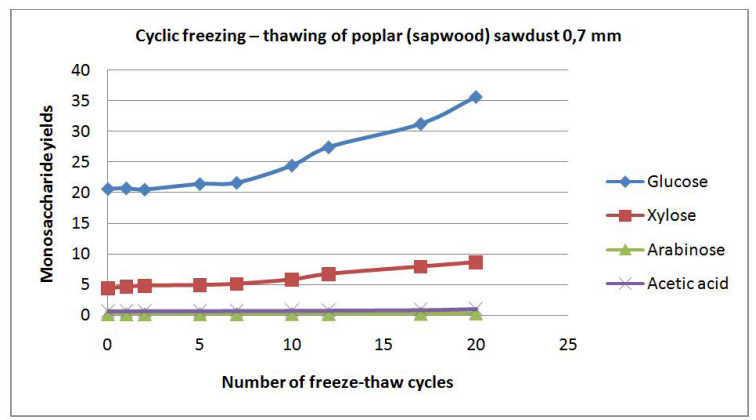

Fig. 4: Dependence of monosaccharide concentration from poplar (sapwood) sawdust $0.7 \mathrm{~mm}$ pretreated by cyclic freezing-thawing after 48 hours enzymatic hydrolysis.

\section{CONCLUSIONS}

Fine milled $0.7 \mathrm{~mm}$ mesh poplar sapwood (Populus alba L.) was subjected to cryolysis pretreatment under mild conditions $-20^{\circ} \mathrm{C}$ to enhance enzymatic accessibility.

The results showed that single freezing of the fully impregnated samples by water or dry in its matter $(5.8 \% \mathrm{MC})$ is a not sufficient pretreatment method. On the other hand, a cyclic freezethaw method was successfully used to enhance monosaccharides' yields. Ultimately, 20 cycles applied on the dendromass dust showed, that the efficiency starts to increase since 10 cycles.

Analyses of cubic tests showed that the slower freezing process, associated with the formation of larger crystals that can disrupt the lignocellulosic structure, has a positive effect on the enzyme accessibility.

\section{ACKNOWLEDGMENT}

This work was supported by the Slovak Research Development Agency under contract No. APVV- 18 - 0533.

\section{REFERENCES}

1. Balbercak, J., Bohacek, S., Medo, P., Ihnat, V., Lubke, H., 2017: Chemical processing of waste wood based agglomerates Part I: Evaluation of properties of fluting liners made of semi-chemical pulp obtained by a mildly alkaline sulphur-free cooking process. Wood Research 62(5): 715-726.

2. Balbercak, J., Bohacek, S., Pazitny, A., Ihnat, V., Lubke, H., 2018: Chemical processing of waste wood based agglomerates part II: Evaluation of properties of fluting liners made of semi-chemical pulp obtained by an alkaline cooking process. Wood Research 63(1): 35-44.

3. Chang, K.L., Thitikorn-Amorn, J., Hsieh, J.F., Ou, B.M., Chen, S.H., Ratanakhanokchai, K., Huang, P.J., Chen, S.T., 2011: Enhanced enzymatic conversion with freeze pretreatment of rice straw. Biomass and Bioenergy 35(1): 90-95. 
4. Deng, Y., Qiu, L., Yao, Y., Qin, M., 2018: A technology for strongly improving methane production from rice straw: freeze-thaw pretreatment. RSC Advances (8): 22643-22651.

5. Echeverria, C., Bazan, G., Gonzalez, J.S., Lescano, L., Pagador, S., Linares, G., 2018: Pretreatment by acidification and freezing on corncob polymers and its enzymatic hydrolysis. Asian Journal of Scientific 11(2): 222-231.

6. Fu, D., Mazza, G., 2011: Aqueous ionic liquid pretreatment of straw. Bioresource Technology (13): 7008-7011.

7. Gigac, J., Fišerová, M., Stankovská, M., Pažitný, A., 2017: Enzymatic hydrolysis of extruded wheat straw with addition of sodium hydroxide and calcium hydroxide. Wood Research 62(6): 919-930.

8. Gökkaya, D.S., Sert, M., Sağlam, M., Yüksel, M., Ballice, L., 2020: Hydrothermal gasification of the isolated hemicellulose and sawdust of the white poplar (Populus alba L.). The Journal of Supercritical Fluids 104846.

9. Halaj, M., Chválová, B., Cepák, V., Lukavský, J., Capek, P., 2018: Searching for microalgal species producing extracellular biopolymers. Chemical Papers 72(10): 2673-2678.

10. Ihnat, V., Boruvka, V., Lubke, H., Babiak, M., Schwartz, J., 2015: Straw pulp as a secondary lignocellulosic raw material and its impact on properties of properties of insulating fiberboards. Part III. Preparation of insulating fiberboards from separately milled lignocellulosic raw materials. Wood Research 60(3): 457-466.

11. Ihnát, V., Lübke, H., Russ, A., Pažitný, A., Borůvka, V., 2018: Waste agglomerated wood materials as a secondary raw material for chipboards and fibreboards. Part II. Preparation and characterisation of wood fibres in terms of their reuse. Wood Research 63(3): 431-442.

12. Jeong, H.S., Jang, S.K., Kim, H.Y., Yeo, H., Choi, J.W, Choiac, I.G., 2016: Effect of freeze storage on hemicellulose degradation and enzymatic hydrolysis by dilute-acid pretreatment of Mongolian oak. Fuel 165: 145-151.

13. Jönsson, L.J., Alriksson, B., Nilvebrant, N.O., 2013: Bioconversion of lignocellulose: inhibitors and detoxification. Biotechnology for biofuels 6(1): 16.

14. Li, J., Wachemo, A.Ch., Yuan, H., Zuo, X., Li, X., 2019a: Natural freezing-thawing pretreatment of corn stalk for enhancing anaerobic digestion performance. Bioresource Technology 288: 121518.

15. Li, J., Wachemo, A.Ch., Yu, G., Li, X., 2019b: Enhanced anaerobic digestion performance of corn stalk pretreated with freezing-thawing and ammonia: An experimental and theoretical study. Journal of Cleaner Production 247: 119112.

16. Mood, S.H., Golfesham, A.H., Tabatabaei, M., Gholamreza, S.J., Gholam, H.N., Mehdi, G., Mehdi, A., 2013: Lignocellulosic biomass to bioethanol, a comprehensive review with a focus on pretreatment. Renewable and Sustainable Energy Reviews 27: 77-93.

17. Moore, E.B., Molinero, V., 2011: Structural transformation in supercooled water controls the crystallization rate of ice. Nature 479(7374): 506-508.

18. Pažitný, A., 2019: Steam explosion of wood particles from fibreboard and particle board with indirect control by enzymatic hydrolysis. Acta Chimica Slovaca 12(2): 185-191.

19. Pažitný, A., Russ, A., Boháček, Š., Bottová, V., Černá, K., 2013: Utilization of energetic grass fibre for modification of recovered fibre properties. Wood Research 58(2): 181-190.

20. Pažitný, A., Russ, A., Boháček, S., Stankovská, M., Suty, S., 2019a: Various lignocellulosic raw materials pretreatment processes utilizable for increasing holocellulose accessibility for hydrolytic enzymes. Part I. Evaluation of wheat straw pretreatment process. Wood Research 64(1): 13-24. 
21. Pažitný, A., Russ, A., Boháček, Š., Stankovská, M., Ihnát, V., Šutý, Š., 2019b: Various lignocellulosic raw materials pretreatment processes utilizable for increasing holocellulose accessibility for hydrolytic enzymes. Part II. Effect of steam explosion temperature on beech enzymatic hydrolysis. Wood Research 64(3): 437-448.

22. Pažitný, A., Russ, A., Boháček, Š., Stankovská, M., Ihnát, V., Šutý, Š., 2020: Effect of steam explosion on enzymatic hydrolysis of various parts of poplar tree. Wood Research 65(4): 579-590.

23. Petráš, R., Mecko, J., Krupová, D., Slamka, M., Pažitný, A., 2019: Aboveground biomass basic density of softwoods tree species. Wood Research 64(2): 205-212.

24. Palmqvist, E., Hahn-Hägerdal, B., 2000: Fermentation of lignocellulosic hydrolysates. II: inhibitors and mechanisms of inhibition. Bioresource Technology 74(1): 25-33.

25. Rego, F., Dias, A.P.S., Casquilho, M., Rosa, F.C., Rodrigues, A., 2019: Fast determination of lignocellulosic composition of poplar biomass by thermogravimetry. Biomass and Bioenergy 122: 375-380.

26. Rooni, V., Raud, M., Kikas, T., 2017: The freezing pretreatment of lignocellulosic material: a cheap alternative for Nordic countries. Energy 139: 1-7.

27. Rowell, R., Pettersen, R., Han, J., Rowell, J., Tshabalala, M., 2005: Cell wall chemistry. In: R. Rowell (Ed.), 2005: Handbook of wood chemistry and wood composites. CRC Press, Madison, Pp 35-74.

28. Russ, A., Schwartz, J., Bohacek, S., Lubke, H., Ihnat, V., Pazitny, A., 2013: Reuse of old corrugated cardboard in constructional and thermal insulating boards. Wood Research 58(3): 505-510.

29. Sasaki, C., Sumitomo, Y., Odashima, K., Asada, C., Nakamura, Y., 2020: Microwaveassisted hydrolysis of cellulose in towel and wheat straw using freeze-thawing with $\mathrm{NaOH}$. Waste and Biomass Valorization 1-9.

30. Sluiter, A., Hames, B., Ruiz, R, Scarlata, C., Sluiter, J., Templeton, D., Crocker, D., 2008: Determination of structural carbohydrates and lignin, BiomassTechnical Report NREL/ TP-510-42618. National Renewable Energy Laboratory (NREL), Golden, CO, USA.

31. Smichi, N., Messaoudi, Y., Moujahed, N., Gargouri, M., 2016: Ethanol production from halophyte Juncus maritimus using freezing and thawing biomass pretreatment. Renewable Energy 85: 1357-1361.

32. Stankovská, M., Fišerová, M., Gigac, J., Pažitný, A., 2018: Effect of alkaline extrusion pretreatment of wheat straw on filtrate composition and enzymatic hydrolysis. Cellulose Chemistry and Technology 52(9-10): 815-822.

33. Su, T.CH., Fang, Z., 2017: One-pot microwave-assisted hydrolysis of cellulose and hemicellulose in selected tropical plant wastes by $\mathrm{NaOH}$-freeze pretreatment. ACS Sustainable Chemistry \& Engineering 5,6: 5166-5174.

34. Taha, M., Foda, M., Shahsavari, E., Aburto-Medina, A., Adetutu, E., Ball, A., 2006: Commercial feasibility of lignocellulose biodegradation: possibilities and challenges. Current Opinion in Biotechnology 38: 190-197.

35. Tuskan, G.A., 2006: The genome of Black cottonwood, Populus trichocarpa (Torr. \& Gray). Science 313(5793): 1596-604.

36. Wang, X.M., Wang, L.J., Yu, M., Chen, H., 2013: Freeze-thaw and sulfuric acid pretreatment of wheat straw for fermentable sugar release. Advanced Materials Research 724-725: 257-260.

37. Yang, Y., Sharma-Shivappa, R.R., Burns, J.C., Cheng, J., 2009: Saccharification and fermentation of dilute-acid-pretreated freeze-dried switchgrass. Energy Fuels 23(11): 5626-5635. 
38. Yazdani, P., Zamani, A., Karimi, K., Taherzadeh, M. J., 2015: Characterization of Nizimuddinia zanardini macroalgae biomass composition and its potential for biofuel production. Bioresource technology 176: 196-202.

39. Yuan, H., Lan, Y., Zhu, J., Wachemo, A.Ch., Li, X., Yu, L., 2019: Effect on anaerobic digestion performance of corn stover by freezing-thawing with ammonia pretreatment. Chinese Journal of Chemical Engineering 27(1): 200-207.

40. Zhu, H., Ma, Q. Sheng, J., Yang, R., 2020: Freeze-thaw repetition as an auxiliary method to promote efficient separation of hemicellulose from poplar. Green Chemistry 22(3): 942-949.

Štefan Boháček*, Andrej Pažitný, Michal Halaj, Jozef Balberčák, Vladimír Kuña

Pulp and Paper Research Institute

Dúbravská Cesta i 4

84I O4 Bratislava

Slovak Republic

*Corresponding author: bohacek@vupc.sk 